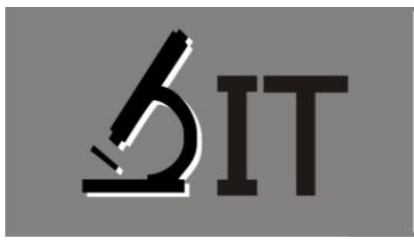

p-ISSN : 2597-8977

e-ISSN : $2597-8985$

Hasnawati*)

Prodi Pendidikan IPA FMIPA Universitas Negeri Makassar

Ratnawaty Maming Prodi Pendidikan IPA FMIPA Universitas Negeri Makassar

Muhammad Aqil RusI Prodi Pendidikan IPA FMIPA Universitas Negeri Makassar
JIT 4 (1) (2020) 36-51

JURNAL IPA TERPADU

http://ojs.unm.ac.id/index.php/ipaterpadu

\section{HUBUNGAN ANTARA PENGETAHUAN DEKLARATIF DAN PENGETAHUAN PROSEDURAL DENGAN KETERAMPILAN PROSES SAINS (KPS) PESERTA DIDIK KELAS VIII SMPN TERAKREDITASI A DI KOTA MAKASSAR}

Abstrak: Penelitian ini bertujuan untuk : 1) mengetahui tingkat pengetahuan deklaratif dan prosedural peserta didik kelas VIII SMPN Terakreditasi A di Kota Makassar. 2) mengetahui tingkat keterampilan proses sains (KPS) peserta didik kelas VIII SMPN Terakreditasi A di Kota Makassar dan 3) menguji hubungan yang positif antara pengetahuan deklaratif dan prosedural dengan KPS peserta didik kelas VIII SMPN Terakreditasi A di Kota Makassar. Penelitian ini adalah penelitian survey dengan populasi seluruh peserta didik kelas VIII SMPN Terakreditasi A di Kota Makassar. Pengambilan sampel menggunakan rumus Slovin. Instrumen yang digunakan dalam penelitian yaitu tes pengetahuan deklaratif dan prosedural IPA, serta tes KPS IPA Hasil penelitian menunjukkan bahwa 1) Pengetahuan deklaratif peserta didik kelas VIII SMPN Terakreditasi A di Kota Makassar tergolong dalam kategori sangat rendah dengan rata-rata skor 3,87 dan pengetahuan prosedural peserta didik kelas tergolong dalam kategori sangat rendah dengan rata-rata skor 5,25. 2) KPS peserta didik kelas VIII SMPN Terakreditasi A di Kota Makassar tergolong dalam kategori sangat rendah dengan rata-rata skor 7,87. 3) Terdapat hubungan yang positif antara pengetahuan deklaratif dan pengetahuan prosedural dengan KPS dengan koefisien korelasi 12,7\%.

Kata Kunci: Pengetahuan Deklaratif, Pengetahuan Prosedural, Keterampilan Proses Sains (KPS).

Abstract: The purposes of this research are: 1) to find out the level of declarative knowledge and procedural knowledge of grade VIII students at Junior High School in Makassar, 2) to find out the level of science process skills of grade VIII students at Junior High School Accredited "A" in Makassar, 3) to test the positive correlation between declarative knowledge and procedural knowledge with science process skills of grade VIII students at Junior High School Accredited "A" in Makassar. This research is a survey research with population all of Grade VIII Students at Junior High School Accredited "A" in Makassar. The results of the study show that 1) declarative knowledge of grade VIII students at Junior High School Accredited " $\mathrm{A}$ " in Makassar has an average total score of 3.87 (very low category) and procedural knowledge has an average total score of 5,25 (very low category), 2) science process skills of grade VIII students at Junior High School Accredited "A" in Makassar has an average total score of 7,87 (very low category) and, 3 ) there is a positive correlation between declarative knowledge and procedural knowledge with science process skills with a correlation coefficient of $12,7 \%$.
Keyword: Declarative and Procedural Knowledge, Science Process Skills *) Correspondence Author:
ahasnawati21@gmail.com 


\section{PENDAHULUAN}

Sesuai dengan standar kompetensi lulusan, sasaran pembelajaran mencakup pengembangan ranah sikap, pengetahuan, dan keterampilan yang dielaborasi untuk setiap satuan pendidikan. Ketiga ranah kompetensi tersebut memiliki lintasan perolehan (proses psikologis) yang berbeda. Sikap diperoleh melalui aktivitas "menerima, menjalankan, menghargai, menghayati, dan mengamalkan". Pengetahuan diperoleh melalui aktivitas "mengingat, memahami, menerapkan, menganalisis, mengevaluasi, dan mencipta". Keterampilan diperoleh melalui aktivitas "mengamati, menanya, mencoba, menalar, menyaji, dan mencipta" (Permendikbud, 2013).

Pengetahuan ilmiah terdiri dari dua domain yaitu pengetahuan isi dan keterampilan proses. Pengetahuan isi (pengetahuan deklaratif) meliputi fakta-fakta, prinsip, model konseptual, teori dan hukum dimana peserta didik mampu memahami dan mengingat. Keterampilan proses (pengetahuan prosedural) merupakan kemampuan yang digunakan dalam sains misalnya mengamati, mengukur, membuat hipotesis, menginterpretasikan data, dan lain-lain yang harus dikuasai oleh peserta didik. Pengetahuan isi dan keterampilan proses sepenuhnya harus dikuasai oleh peserta didik pada semua mata pelajaran agar memahami konsep-konsep sains dan mampu menerapkannya dalam kehidupan sehari-hari (Hırca, 2013).

Salah satu keterampilan yang digunakan dalam proses pembelajaran IPA saat ini adalah keterampilan proses sains. Keterampilan proses sains dapat diartikan sebagai wawasan atau anutan pengembangan keterampilan-keterampilan intelektual, sosial, dan fisik yang bersumber dari kemampuan-kemampuan yang pada prinsipnya ada dalam diri peserta didik (Tawil \& Liliasari, 2014). Senada dengan hal tersebut, Kurniati (2001) mengungkapkan bahwa pendekatan keterampilan proses sains adalah pendekatan yang memberi kesempatan kepada peserta didik agar dapat menemukan fakta, mengembangkan konsep-konsep, melalui kegiatan dan atau pengalaman-pengalaman seperti ilmuan.

Keterampilan proses sains melibatkan keterampilan-keterampilan kognitif atau intelektual, manual, dan sosial. Keterampilan kognitif atau intelektual menunjukkan bahwa dengan melakukan keterampilan proses, siswa menggunakan pikirannya. Keterampilan manual terlibat dalam penggunaan alat dan bahan, pengukuran, penyusunan atau perakitan alat. Sedangkan keterampilan sosial yang dimaksud adalah keterampilan peserta didik berinteraksi dengan sesamanya dalam melaksanakan kegiatan belajar mengajar. Keterampilan kognitif atau intelektual dan keterampilan manual berhubungan dengan metakognitif peserta didik. (Rustaman, 2005).

Menurut Rinaldi (2017), metakognitif penting untuk keberhasilan belajar karena memungkinkan individu untuk mengelola keterampilan kognitif mereka dan untuk menentukan kelemahan mereka yang dapat diperbaiki dengan membangun keterampilan kognitif yang baru. Komponen metakognitif dibagi menjadi 2, yaitu pengetahuan kognisi dan regulasi kognisi. Pengetahuan tentang kognisi merujuk kepada pada sesuatu yang diketahui oleh individu tentang kemampuan kognitif mereka sendiri atau tentang kognitif secara umum. Pengetahuan metakognitif dapat dibagi menjadi tiga jenis yaitu: deklaratif, prosedural, dan kondisional. Pada penelitian ini hanya mengarah kepada dua jenis pengetahuan metakognitif yaitu prosedural dan deklaratif.

Hasil penelitian Hayu, Ardi, \& Febri (2017) pada siswa kelas VIII di MTsN Kuranji Padang disimpulkan bahwa pengetahuan prosedural memiliki nilai sebesar 34,56\% dengan kriteria kurang sekali dan pengetahuan deklaratif memiliki nilai sebesar 35,14\% dengan kriteria kurang sekali pada mata pelajaran IPA. Hal ini menunjukkan bahwa pengetahuan deklaratif dan prosedural peserta didik masih perlu ditingkatkan.

Proses belajar mengajar mempunyai kaitan dengan berbagai faktor, salah satu faktornya adalah kelayakan dari sebuah sekolah. Sebuah sekolah akan mendapatkan status terakreditasi jika keadaan sekolah yang sebenarnya memenuhi kriteria dari standar yang ditetapkan. Bagi sekolah yang terakreditasi diklasifikasikan menjadi tiga tahapan, yaitu A (amat baik), B (baik), dan C (cukup). 
Sekolah yang mendapatkan status terakreditasi A sudah dapat dijamin kelayakan sarana dan prasarana pendidikan dan juga pendidik dan tenaga pendidiknya. Sekolah terakreditasi A yang sarana dan prasarananya baik dapat meningkatkan mutu dari peserta didik. Salah satu sarana dan prasarana yang wajib di sekolah adalah laboratorium. Dalam proses pembelajaran IPA mengharuskan peserta didik untuk melakukan praktikum atau eksperimen di dalam laboratorium pada materi tertentu. Kegiatan eksperimen atau praktikum yang dilakukan peserta didik dapat meningkatkan keterampilan proses sains pengetahuan prosedural, dan juga deklaratif peserta didik (Lestari, Mursali, dan Royani, 2018; Wildayati, Sartika, dan Lestari, 2020; Ardhana, 2020).

Menurut Anderson dan Krathwohl (2015), bahwa pengetahuan deklaratif merupakan salah satu aspek yang disebut disciplinary knowledge, yakni cara ilmuwan memikirkan suatu fenomena dalam disiplin ilmunya. Dalam kemampuan deklaratif terdiri dari tiga indikator yaitu kemampuan tentang klasifikasi dan kategori, kemampuan tentang prinsip dan generalisasi, serta kemampuan tentang teori, model, dan struktur.

Menurut Hayu, Ardi, \& Yanti (2017), pengetahuan prosedural adalah pengetahuan bagaimana melakukan sesuatu, bagaimana melakukan langkah-langkah atau startegi-strategi dalam suatu proses pemecahan masalah pembelajaran IPA. Pengetahuan prosedural merupakan pengetahuan yang tidak perlu dicari dalam memori jangka panjang. Generalisasi merupakan proses yang dapat memperluas prosedur penerapan pengenalan pola. Berdasarkan penjelasan sebelumnya, maka pengetahuan prosedural adalah pengetahuan peserta didik untuk menyelesaikan masalah dengan langkah-langkah secara sistematis.

Ilmu Pengetahuan Alam (IPA) berhubungan dengan cara mencari tahu tentang alam secara terencana dan sistematis. IPA bukanlah sekedar kumpulan pengetahuan yang berupa fakta-fakta, konsep-konsep, atau prinsip-prinsip tetapi juga merupakan proses mencari dan menemukan. Proses pembelajaran IPA sebaiknya menekankan pada pemberian pengalaman langsung kepada peserta didik melalui langkah-langkah kerja ilmiah sebagaimana dilakukan oleh para ilmuwan. Dalam praktik pembelajaran, maka kegiatan belajar melalui proses kerja ilmiah akan melibatkan serangkaian keterampilan yang disebut dengan keterampilan proses sains (science process skill) (Jufri, 2017).

Menurut Keil (2009) keterampilan proses sains tidak dapat dipisahkan dari praktek IPA dan memainkan peran kunci baik dalam pembelajaran formal dan informal konten IPA. Mereka memiliki kualitas yang abadi yang akan berkontribusi pada kemampuan peserta didik untuk menjawab pertanyaan dan memecahkan masalah bahkan ketika basis informasi IPA dan teknologi berubah. Oleh karena itu, kepemilikan keterampilan ini merupakan dasar untuk penyelidikan ilmiah dan pengembangan keterampilan intelektual yang diperlukan untuk mempelajari konsep IPA.

Lebih lanjut Rezba (2007) juga mengemukakan bahwa keterampilan proses sains terdiri dari dua bagian, yakni keterampilan proses sains dasar dan keterampilan proses sains terintegrasi. Keterampilan proses sains dasar terdiri dari:

1) Observing (mengamati/mengobservasi)

2) Communicating (mengkomunikasikan)

3) Classifying (mengklasifikasikan)

4) Measuring metrically (mengukur secara metris)

5) Inferring (menginferensi)

6) Predicting (memprediksi)

Keterampilan proses sains terintegrasi menurut Rezba (2007) yaitu:

1) Identifying variables (mengidentifikasi variabel)

2) Constructing a table of data (membuat sebuah tabel dari data)

3) Constructing a graph (membuat grafik)

4) Describing relationships between variables (mendeskripsikan hubungan antar variabel)

5) Acquiring and processing your own data (mengambil dan memproses data) 
6) Designing investigations (mendesain penyelidikan)

7) Experimenting (melakukan eksperimen)

Pengetahuan deklaratif adalah pengetahuan tentang sesuatu yang bersifat faktual. Kurniati (2001) mengungkapkan bahwa pendekatan keterampilan proses sains adalah pendekatan yang memberi kesempatan kepada peserta didik agar dapat menemukan fakta, mengembangkan konsep-konsep, melalui kegiatan dan atau pengalaman-pengalaman seperti ilmuwan. Berdasarkan penjelasan tersebut dapat dikatakan bahwa terdapat hubungan antar keduanya.

Pengetahuan prosedural juga memiliki hubungan dengan keterampilan proses sains. $\mathrm{Di}$ mana keterampilan proses sains juga melibatkan keterampilan penggunaan alat dan bahan, melakukan pengukuran, penyusunan atau perakitan alat dimana hal tersebut berkaitan dengan pengetahuan prosedural. Menurut Hayu, Ardi, \& Yanti (2017) pengetahuan prosedural adalah pengetahuan tentang cara melakukan sesuatu, melakukan langkah-langkah atau strategi-strategi dalam suatu proses pemecahan masalah.

Berdasarkan penjelasan-penjelasan tersebut maka disimpulkan bahwa pengetahuan deklaratif dan pengetahuan prosedural memiliki hubungan dengan keterampilan proses sains. Dalam keterampilan proses sains, peserta didik diberikan kesempatan untuk menemukan pengetahuan yang terkait dengan fakta sehingga keterampilan proses sains dikaitkan dengan pengetahuan deklaratif. Keterampilan proses sains juga berhubungan dengan pengetahuan prosedural karena berdasarkan penjelasan sebelumnya, keduanya merupakan bagian dari keterampilan proses sains. Hal ini dapat dilihat dari indikator kedua pengetahuan tersebut, di mana indikator prosedural yaitu langkah-langkah percobaan berhubungan dengan indikator dari keterampilan proses sains yaitu mengamati atau mengobservasi.

\section{METODE}

Jenis penelitian yang digunakan adalah metode penelitian survei. Penelitian ini diarahkan untuk mengetahui pengetahuan deklaratif, pengetahuan prosedural, dan keterampilan proses sains peserta didik pada pembelajaran IPA pada materi tentang gaya dan gerak. Penelitian dilaksanakan pada Semester Ganjil Tahun Pelajaran 2019/2020. Penelitian dilaksanakan di 13 SMPN terakreditasi A di Kota Makassar.

Populasi dari penelitian ini adalah seluruh peserta didik kelas VIII SMPN yang terakreditasi A di Kota Makassar sebanyak 10314. Pengambilan sampel menggunakan rumus Slovin dengan cara Random Sampling Class. Instrumen yang digunakan dalam penelitian ini yaitu tes pengetahuan deklaratif IPA, tes pengetahuan prosedural IPA, dan tes keterampilan proses sains IPA.

Data pengetahuan deklaratif, peserta didik diperoleh melalui pemberian tes pengetahuan deklaratif dalam bentuk pilihan ganda dengan jumlah soal sebanyak 10 nomor. Instrumen tes pengetahuan prosedural yang digunakan dalam bentuk pilihan ganda dengan jumlah soal sebanyak 10 nomor. Tes keterampilan proses sains merupakan tipe soal pilihan ganda dengan jumlah soal sebanyak 20 nomor. 
Kriteria pengkategorian skor dapat dilihat pada Tabel 1 berikut.

Tabel 1. Pedoman Pengkategorian Skor

\begin{tabular}{cc}
\hline Tingkat Penguasaan & Kriteria \\
\hline $90 \%-100 \%$ & Sangat Tinggi \\
$80 \%-89 \%$ & Tinggi \\
$70 \%-79 \%$ & Sedang \\
$60 \%-69 \%$ & Rendah \\
$<59 \%$ & Sangat Rendah \\
\hline
\end{tabular}

(Arifin, 2014)

Sementara itu, untuk kriteria pengkategorian per indikator untuk skor 3 dapat dilihat pada Tabel 2 berikut.

Tabel 2. Pedoman Pengkategorian pada Setiap Indikator untuk Skor 3

\begin{tabular}{cc}
\hline Skor & Kriteria \\
\hline $2,97 \leq X$ & Sangat Tinggi \\
$1,98 \leq X<2,97$ & Tinggi \\
$0,99 \leq X<1,98$ & Rendah \\
$0 \leq X<0,99$ & Sangat Rendah \\
\hline
\end{tabular}

Kriteria pengkategorian per indikator untuk skor 4 dapat dilihat pada Tabel 3 berikut.

Tabel 3. Pedoman Pengkategorian pada Setiap Indikator untuk Skor 4

\begin{tabular}{cc}
\hline Skor & Kriteria \\
\hline $3,6 \leq X$ & Sangat Tinggi \\
$3 \leq X<3,6$ & Tinggi \\
$2 \leq X<3$ & Sedang \\
$1 \leq X<2$ & Rendah \\
$0 \leq X<1$ & Sangat Rendah \\
\hline & (Ratumanan \& Laurens, 2003)
\end{tabular}

Kriteria pengkategorian per indikator untuk skor 5 dapat dilihat pada Tabel 4 berikut.

Tabel 4. Pedoman Pengkategorian pada Setiap Indikator untuk Skor 5

\begin{tabular}{cc}
\hline Skor & Kriteria \\
\hline $4,5 \leq X$ & Sangat Tinggi \\
$4 \leq X<4,5$ & Tinggi \\
$3 \leq X<4$ & Sedang \\
$2 \leq X<3$ & Rendah \\
$X<2$ & Sangat Rendah \\
\hline
\end{tabular}

(Ratumanan \& Laurens, 2003)

Data yang diperoleh dari sampel penelitian ini berupa data kuantitatif. Hasil penelitian tes pengetahuan deklaratif, tes pengetahuan prosedural, dan tes keterampilan proses sains peserta didik yang diolah menggunakan teknik analisis statistik deskriptif dan analisis inferensial dimana di 
dalam analisis inferensial terdapat uji normalitas, uji korelasi, uji regresi linier sederhana, dan uji regresi linier berganda. Analisis statistik deskriptif bertujuan untuk mendeskripsikan tingkat pengetahuan deklaratif, pengetahuan prosedural, dan keterampilan proses sains yang diperoleh peserta didik. Analisis inferensial dilakukan untuk menguji hipotesis penelitian dan hasil analisis dan dari hasil analisi tersebut akan ditarik suatu kesimpulan.

Untuk mengetahui keeratan hubungan dilakukan dengan memasukkan koefisien korelasi ( $r$ ) hasil perhitungan kedalam tabel interpretasi $r$. Untuk dapat memberi interpretasi terhadap kuatnya hubungan itu, maka dapat digunakan pedoman seperti pada tabel 5 berikut.

Tabel 5. Interpretasi Koefisien Korelasi

\begin{tabular}{cc}
\hline Interval Koefisien & Tingkat Hubungan \\
\hline $0,80-1,00$ & Sangat Tinggi \\
$0,60-0,79$ & Tinggi \\
$0,40-0,59$ & Sedang \\
$0,20-0,39$ & Rendah \\
$0,00-0,19$ & Sangat Rendah \\
\hline & (Sugiyono, 2013)
\end{tabular}

\section{HASIL DAN PEMBAHASAN}

\section{Hasil Penelitian}

\section{a. Analisis Statistik Deskriptif}

Hasil analisis statistik deskriptif diperoleh dari hasil tes untuk materi gerak dan gaya. Tabeltabel berikut menunjukkan hasil analisis untuk pengetahuan deklaratif, pengetahuan prosedural, dan keterampilan proses sains.

1) Pengetahuan Deklaratif

Rata-rata skor pengetahuan deklaratif yaitu 3,87 di mana berdasarkan Tabel 6 termasuk dalam kategori sangat rendah. Tabel 6 memperlihatkan pengkategorian skor pengetahuan deklaratif berdasarkan pada Tabel 1 .

Tabel 6.Pengkategorian Skor Pengetahuan Deklaratif

\begin{tabular}{ccc}
\hline Skor & Frekuensi & Kriteria \\
$9-10$ & 0 & Sangat Tinggi \\
$8-8,9$ & 5 & Tinggi \\
$7-7,9$ & 30 & Sedang \\
$6-6,9$ & 42 & Rendah \\
$<5,9$ & 327 & Sangat Rendah \\
\hline
\end{tabular}

Berdasarkan Tabel 7, rata-rata skor pengetahuan deklaratif yang diperoleh pada indikator pengenalan nama alat dari keseluruhan jumlah peserta didik yaitu sebesar 1,29 di mana skor tersebut termasuk dalam kategori rendah. 
Tabel 7. Pengkategorian Skor Indikator Pengenalan Nama Alat

\begin{tabular}{ccc}
\hline Skor & Frekuensi & Kriteria \\
\hline $2,97 \leq X$ & 20 & Sangat Tinggi \\
$1,98 \leq X<2,97$ & 136 & Tinggi \\
$0,99 \leq X<1,98$ & 191 & Rendah \\
$0 \leq X<0,99$ & 57 & Sangat Rendah \\
\hline
\end{tabular}

Tabel 8 menunjukkan skor rata-rata pengetahuan deklaratif yang diperoleh pada indikator pengenalan fungsi alat dari keseluruhan jumlah peserta didik yaitu sebesar 1,53 di mana skor tersebut termasuk dalam kategori rendah.

Tabel 8. Pengkategorian Skor Indikator Pengenalan Fungsi Alat

\begin{tabular}{ccc}
\hline Skor & Frekuensi & Kriteria \\
\hline $3,6 \leq X$ & 11 & Sangat Tinggi \\
$3 \leq X<3,6$ & 64 & Tinggi \\
$2 \leq X<3$ & 132 & Sedang \\
$1 \leq X<2$ & 120 & Rendah \\
$0 \leq X<1$ & 77 & Sangat Rendah \\
\hline
\end{tabular}

Pada Tabel 9 rata-rata skor pengetahuan deklaratif yang diperoleh pada indikator menentukan fungsi alat dari keseluruhan jumlah peserta didik yaitu sebesar 1,04 di mana skor tersebut termasuk dalam kategori rendah.

Tabel 9. Pengkategorian Skor Indikator Menentukan Fungsi Alat

\begin{tabular}{ccc}
\hline Skor & Frekuensi & Kriteria \\
\hline $2,97 \leq X$ & 20 & Sangat Tinggi \\
$1,98 \leq X<2,97$ & 136 & Tinggi \\
$0,99 \leq X<1,98$ & 191 & Rendah \\
$0 \leq X<0,99$ & 57 & Sangat Rendah \\
\hline
\end{tabular}

2) Pengetahuan Prosedural

Rata-rata skor pengetahuan prosedural yaitu 5,25 dimana skor ini jika dilihat pada pengkategorian skor pengetahuan prosedural pada Tabel 10 termasuk dalam kategori sangat rendah.

Tabel 10. Pengkategorian Skor Pengetahuan Prosedural

\begin{tabular}{ccc}
\hline Skor & Frekuensi & Kriteria \\
\hline $9-10$ & 0 & Sangat Tinggi \\
$8-8,9$ & 5 & Tinggi \\
$7-7,9$ & 30 & Sedang \\
$6-6,9$ & 42 & Rendah \\
$<5,9$ & 327 & Sangat Rendah \\
\hline
\end{tabular}

3) Keterampilan Proses Sains

Rata-rata skor keterampilan prose sains yaitu 7,87 di mana skor ini jika dilihat pada pengkategorian keterampilan pemecahan masalah pada Tabel 11 termasuk dalam kategori sangat 
rendah. Pengkategorian pada Tabel 11 berdasarkan skor yang diperoleh peserta didik dan dianalisis dengan pedoman pengkategorian pada Tabel 1.

Tabel 11. Pengkategorian Skor Keterampilan Proses Sains

\begin{tabular}{ccc}
\hline Tingkat Penguasaan & Frekuensi & Kriteria \\
\hline $18-20$ & 0 & Sangat Tinggi \\
$16-17$ & 0 & Tinggi \\
$14-15$ & 14 & Sedang \\
$12-13$ & 38 & Rendah \\
$<11$ & 352 & Sangat Rendah \\
\hline
\end{tabular}

Berdasarkan Tabel 12 rata-rata skor keterampilan proses sains untuk indikator mengamati yaitu sebesar 1,61 di mana skor tersebut termasuk dalam kategori rendah.

Tabel 12. Pengkategorian Skor Indikator Mengamati

\begin{tabular}{ccc}
\hline Skor & Frekuensi & Kriteria \\
\hline $2,97 \leq X$ & 20 & Sangat Tinggi \\
$1,98 \leq X<2,97$ & 136 & Tinggi \\
$0,99 \leq X<1,98$ & 191 & Rendah \\
$0 \leq X<0,99$ & 57 & Sangat Rendah \\
\hline
\end{tabular}

Tabel 13 menunjukkan rata-rata skor keterampilan proses sains pada indikator mengkomunikasikan dari keseluruhan jumlah peserta didik yaitu sebesar 1,30 di mana skor tersebut termasuk dalam kategori rendah.

Tabel 13. Pengkategorian Skor Indikator Mengkomunikasikan

\begin{tabular}{ccc}
\hline Skor & Frekuensi & Kriteria \\
\hline $2,97 \leq X$ & 20 & Sangat Tinggi \\
$1,98 \leq X<2,97$ & 136 & Tinggi \\
$0,99 \leq X<1,98$ & 191 & Rendah \\
$0 \leq X<0,99$ & 57 & Sangat Rendah \\
\hline
\end{tabular}

Pada Tabel 14 rata-rata skor keterampilan proses sains pada indikator mengklasifikasikan dari keseluruhan jumlah peserta didik yaitu sebesar 1,75 di mana skor tersebut termasuk dalam kategori sangat rendah.

Tabel 14. Pengkategorian Skor Indikator Mengklasifikasikan

\begin{tabular}{ccc}
\hline Skor & Frekuensi & Kriteria \\
\hline $4,5 \leq X$ & 0 & Sangat Tinggi \\
$4 \leq X<4,5$ & 23 & Tinggi \\
$3 \leq X<4$ & 87 & Sedang \\
$2 \leq X<3$ & 116 & Rendah \\
$X<2$ & 178 & Sangat Rendah \\
\hline
\end{tabular}

Tabel 15 menunjukkan rata-rata skor keterampilan proses sains yang diperoleh pada indikator mengukur secara metris dari keseluruhan jumlah peserta didik yaitu sebesar 0,95 di mana skor tersebut termasuk dalam kategori sangat rendah. 
Tabel 15. Pengkategorian skor indikator mengukur secara metris

\begin{tabular}{ccc}
\hline Skor & Frekuensi & Kriteria \\
\hline $2,97 \leq X$ & 20 & Sangat Tinggi \\
$1,98 \leq X<2,97$ & 136 & Tinggi \\
$0,99 \leq X<1,98$ & 191 & Rendah \\
$0 \leq X<0,99$ & 57 & Sangat Rendah \\
\hline
\end{tabular}

Pada Tabel 16, rata-rata skor keterampilan proses sains yang diperoleh pada indikator menginferensi dari keseluruhan jumlah peserta didik yaitu sebesar 0,88 di mana skor tersebut termasuk dalam kategori sangat rendah.

Tabel 16. Pengkategorian Skor Indikator Menginferensi

\begin{tabular}{ccc}
\hline Skor & Frekuensi & Kriteria \\
\hline $2,97 \leq X$ & 20 & Sangat Tinggi \\
$1,98 \leq X<2,97$ & 136 & Tinggi \\
$0,99 \leq X<1,98$ & 191 & Rendah \\
$0 \leq X<0,99$ & 57 & Sangat Rendah \\
\hline
\end{tabular}

Tabel 17 menunjukkan rata-rata skor keterampilan proses sains pada indikator memprediksi yaitu sebesar 1,33 di mana skor tersebut termasuk dalam kategori rendah.

Tabel 17. Pengkategorian Skor Indikator Memprediksi

\begin{tabular}{ccc}
\hline Skor & Frekuensi & Kriteria \\
\hline $2,97 \leq X$ & 20 & Sangat Tinggi \\
$1,98 \leq X<2,97$ & 136 & Tinggi \\
$0,99 \leq X<1,98$ & 191 & Rendah \\
$0 \leq X<0,99$ & 57 & Sangat Rendah \\
\hline
\end{tabular}

\section{b. Analisis Inferensial}

Hasil analisis inferensial menggunakan uji normalitas data skor pengetahuan deklaratif, data skor pengetahuan prosedural, dan keterampilan proses sains peserta didik dapat dilihat pada tabel 18, 19, dan 20 berikut.

Tabel 18. Hasil Perhitungan Uji Normalitas Pengetahuan Deklaratif

\begin{tabular}{cccccc}
\hline Kelas VIII & $\mathbf{N}$ & Taraf Signifikan & $\boldsymbol{X}^{2}$ hitung & $\boldsymbol{X}^{2}$ tabel & Kesimpulan \\
\hline 404 & 0,05 & 14,1689 & 16,9 & Terdistribusi Normal \\
\hline
\end{tabular}

Pada Tabel 18 dapat diketahui bahwa Chi kuadrat $=14,1689$, dengan derajat kebebasan $(\mathrm{dk})$ 10-1 =9, dengan taraf signifikansi sebesar $5 \%$ atau $\propto=0,05$ didapatkan bahwa $X^{2}{ }_{(0.95)(9)}=16,9$. Karena $X^{2}{ }_{\text {hitung }}<X_{(0.95)(9)}^{2}$, maka dinyatakan bahwa data skor pengetahuan deklaratif terdistribusi normal. 
Tabel 19. Hasil Perhitungan Uji Normalitas Pengetahuan Prosedural

\begin{tabular}{cccccc}
\hline Kelas VIII & $\mathbf{N}$ & Taraf Signifikan & $\boldsymbol{X}^{\mathbf{2}}$ hitung & $\boldsymbol{X}^{\mathbf{2}}$ tabel & Kesimpulan \\
\hline & 404 & 0,05 & 13,8264 & 16,9 & Terdistribusi Normal \\
\hline
\end{tabular}

Pada Tabel 19 dapat diketahui bahwa Chi kuadrat = 13,8264, dengan derajat kebebasan (dk) 10-1 =9, dengan taraf signifikansi sebesar $5 \%$ atau $\propto=0,05$ didapatkan bahwa $X^{2}{ }_{(0.95)(9)}=16,9$.

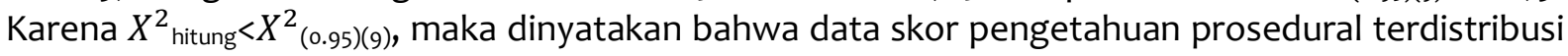
normal.

Tabel 20. Hasil Perhitungan Uji Normalitas Keterampilan Proses Sains

\begin{tabular}{cccccc}
\hline Kelas VIII & N & Taraf Signifikan & $\boldsymbol{X}^{\mathbf{2}}$ hitung & $\boldsymbol{X}^{\mathbf{2}}$ tabel & Kesimpulan \\
\hline & 404 & 0,05 & 14,0026 & 16,9 & Terdistribusi Normal \\
\hline
\end{tabular}

Pada Tabel 20 dapat diketahui bahwa Chi kuadrat $=14,0026$, dengan derajat kebebasan (dk) 10-1 =9, dengan taraf signifikansi sebesar $5 \%$ atau $\propto=0,05$ didapatkan bahwa $X^{2}{ }_{(0.95)(9)}=16,9$. Karena $X^{2}{ }_{\text {hitung }}<X^{2}{ }_{(0.95)(9)}$, maka dinyatakan bahwa data skor keterampilan proses sains terdistribusi normal.

Berdasarkan tabel diatas diketahui bahwa data skor pengetahuan deklaratif, data skor pengetahuan prosedural, dan data skor keterampilan proses sains peserta didik berdistribusi normal. Uji selanjutnya yang dilakukan adalah uji korelasi.

Uji korelasi digunakan untuk melihat hubungan pengaruh suatu variabel dengan variabel lain. Uji korelasi dilakukan dengan uji korelasi product moment. Uji korelasi digunakan untuk melihat hubungan antara pengetahuan deklaratif dengan keterampilan proses sains, hubungan antara pengetahuan prosedural dengan keterampilan proses sains, hubungan antara pengetahuan deklaratif dan pengetahuan prosedural dengan keterampilan proses sains.

Tabel 21. Hasil Perhitungan Uji Korelasi Pengetahuan Deklaratif dengan Keterampilan Proses Sains

\begin{tabular}{ccc}
\hline Korelasi & Koefisien Korelasi & Koefisien Determinasi \\
\hline$r_{\mathrm{xy}}$ & 0,115 & 0,0132 \\
\hline
\end{tabular}

Berdasarkan pada tabel 21 hasil pengujian korelasi antara pengetahuan deklaratif dengan keterampilan proses sains peserta didik sebesar 0,115 di mana angka ini dapat dilihat pada tabel tingkat hubungan berdasarkan interval korelasi berada pada kategori sangat rendah. Dapat pula dihitung koefisien determinasi untuk mengetahui pengaruh pengetahuan deklaratif dengan keterampilan proses sains dengan cara mengkuadratkan nilai r. Hasil hitung koefisien determinasi seperti pada Tabel 21 adalah 0,0132.

Tabel 22. Hasil Perhitungan Uji Korelasi Pengetahuan Prosedural dengan Keterampilan Proses Sains

\begin{tabular}{ccc}
\hline Korelasi & Koefisien Korelasi & Koefisien Determinasi \\
\hline$r_{\mathrm{xy}}$ & 0,343 & 0,117 \\
\hline
\end{tabular}

Tabel 22 menunjukkan hasil pengujian korelasi antara pengetahuan prosedural dengan keterampilan proses sains peserta didik sebesar 0,343. Hasil ini menggambarkan tingkat korelasi yang rendah sesuai dengan tabel. Perhitungan koefisien determinasi juga dilakukan untuk 
mengetahui pengaruh pengetahuan prosedural dengan keterampilan proses sains dengan cara mengkuadratkan nilai r. Hasil hitung koefisien determinasi dapat dilihat pada tabel 22 yaitu sebesar 0,117 .

Tabel 23. Hasil Perhitungan Uji Korelasi Pengetahuan Deklaratif Dan Pengetahuan Prosedural Dengan Keterampilan Proses Sains

\begin{tabular}{ccc}
\hline Korelasi & Koefisien Korelasi & Koefisien Determinasi \\
\hline$r_{x_{1} x_{2} y}$ & 0,357 & 0,127 \\
\hline
\end{tabular}

Berdasarkan pada tabel 23 hasil pengujian korelasi antara pengetahuan deklaratif dan pengetahuan prosedural dengan keterampilan proses sains peserta didik sebesar 0,357 dan berada pada kategori rendah. Hasil hitung koefisien determinasi sesuai pada Tabel 23 yaitu sebesar 0,127.

Menurut Hasan (2012) apabila koefisien korelasi dikuadratkan akan menjadi koefisien Penentu (KP) atau koefisien determinasi yang artinya penyebab perubahan pada variabel $Y$ yang datang dari variabel $X$, sebesar kuadrat koefisien korelasinya. Koefisien penentu ini menjelaskan besarnya pengaruh nilai suatu variabel (variabel $X$ ) terhadap variasi nilai variabel lainnya (variabel Y).

Hasil analisis regresi linier sederhana digunakan untuk mengetahui adanya hubungan yang positif atau negative antara dua variabel. Di mana pada pengujian ini peneliti akan menganalisis hubungan antara pengetahuan deklaratif dengan keterampilan proses sains dan pengetahuan prosedural dengan keterampilan proses sains peserta didik.

Hasil pengujian regresi linier sederhana antara pengetahuan deklaratif dengan keterampilan proses sains diperoleh nilai a sebesar sebesar 6,91 dan nilai b sebesar 0,2482 sehingga didapatkan persamaan $\widehat{Y}=6,91+0,2482 X+\varepsilon$. Persamaan ini menunjukkan bahwa ketika pengetahuan deklaratif peserta didik konstan maka rata-rata keterampilan proses sains peserta didik sebesar 6,91, sedangkan ketika pengetahuan deklaratif peserta didik sebesar 0,2482 menunjukkan bahwa setiap kenaikan 1 konstanta pada pengetahuan deklaratif akan meningkatkan keterampilan proses sains peserta didik sebesar 6,91. Diketahui bahwa koefisien determinasi $\left(r^{2}\right)$ yang diperoleh dari uji korelasi sebesar 0,0132 atau 1,32\% berarti bahwa 1,32\% pengaruh variabel $X$ dengan variabel $Y$, sehingga standar error yang diperoleh adalah $\varepsilon=1-r^{2}=1-0,0132=0,9868$ mencerminkan adanya pengaruh variabel lain yang tidak diteliti sebesar 0,9868 atau 98,68\%.

Untuk uji signifikansi regresi antara pengetahuan deklaratif dengan keterampilan proses sains didapatkan bahwa $F_{\text {hitung }}$ 9,9077 dan $F_{\text {tabel }}$ untuk $a=5 \%, d b(b / a)=1$, sedangkan db $(S)=404-2$ $=402$ didapatkan $F$ tabel sebesar 3,84, sehingga dapat dikatakan $F_{\text {hitung }}>F_{\text {tabel }(\propto 0,05)}=$ 9,9077 > 3,84, karena $\mathrm{F}_{\text {hitung }}$ lebih besar dari pada $\mathrm{F}_{\text {tabel }}$ maka $\mathrm{H}_{\mathrm{o}}$ ditolak, dengan demikian regresi $\mathrm{Y}$ atas $\mathrm{X}$ adalah signifikan.

Untuk uji liniearitas regresi antara pengetahuan deklaratif dengan keterampilan proses sains didapatkan bahwa $F_{\text {hitung }}-1,3570$ dan $F_{\text {tabel }}$ untuk $\alpha=5 \%$, db (Tc) $=9-2=7$, sedangkan $\mathrm{db}(\mathrm{G})=$ 404-9 = 395 didapatkan $F_{\text {tabel }}$ sebesar 2,10, sehingga dapat dikatakan $F_{\text {hitung }}<F_{\text {tabel }(\propto 0,05)}=-1,3570$ $<2,01$, karena $\mathrm{F}_{\text {hitung }}$ lebih kecil dari pada $\mathrm{F}_{\text {tabel }}$ maka $\mathrm{H}_{\mathrm{o}}$ diterima, dengan demikian regresi $\mathrm{Y}$ atas $\mathrm{X}$ adalah tidak berpola linier.

Hasil pengujian regresi linier sederhana antara pengetahuan prosedural dengan keterampilan proses sain diperoleh nilai a a sebesar 3,13, dan nilai b sebesar 0,9046 sehingga didapatkan persamaan $\hat{Y}=3,13+0,9046 \mathrm{X}$ ini menunjukkan bahwa ketika pengetahuan prosedural peserta didik konstan maka rata-rata keterampilan proses sains peserta didik sebesar 3,13, sedangkan ketika pengetahuan prosedural peserta didik sebesar 0,9046 menunjukkan bahwa setiap kenaikan 1 konstanta pada pengetahuan prosedural akan meningkatkan keterampilan proses sains peserta didik sebesar 3,13. Diketahui bahwa koefisien determinasi $\left(r^{2}\right)$ yang diperoleh 
dari uji korelasi sebesar 0,117 atau 11,7\% berarti bahwa 11,7\% pengaruh variabel $X$ dengan variabel $Y$, sehingga standar error yang diperoleh adalah $\varepsilon=1-r^{2}=1-0,117=0,883$ mencerminkan adanya pengaruh variabel lain yang tidak diteliti sebesar 0,883 .

Untuk uji signifikansi regresi antara pengetahuan prosedural dengan keterampilan proses sains didapatkan bahwa $F_{\text {hitung }} 27,531$ dan $F_{\text {tabel }}$ untuk $a=5 \%, d b(b / a)=1$, sedangkan $d b(S)=404-2=$ 402 didapatkan $\mathrm{F}$ table sebesar 3,84, sehingga dapat dikatakan $\mathrm{F}_{\text {hitung }}>F_{\text {tabel }(\propto 0,05)}=27,531>3,84$, karena $\mathrm{F}_{\text {hitung }}$ lebih besar dari pada $\mathrm{F}_{\text {tabel }}$ maka $\mathrm{H}_{\mathrm{o}}$ ditolak, dengan demikian regresi $\mathrm{Y}$ atas $\mathrm{X}$ adalah signifikan.

Untuk uji linearitas regresi didapatkan bahwa $F_{\text {hitung }}-3,156$ dan $F_{\text {tabel }}$ untuk $a=5 \%, d b(T c)=$ 10-2 =8, sedangkan db $(G)=404-10=394$ didapatkan $F$ table sebesar 1,94, sehingga dapat dikatakan $F_{\text {hitung }}<F_{\text {tabel }}(\propto 0,05)=-3,156<1,94$, karena $\mathrm{F}_{\text {hitung }}$ lebih kecil dari pada $\mathrm{F}_{\text {tabel }}$ maka $\mathrm{H}_{0}$ diterima, dengan demikian regresi $\mathrm{Y}$ atas $\mathrm{X}$ adalah tidak berpola linier.

Hasil analisis regresi linier berganda digunakan untuk mengetahui adanya hubungan yang positif atau negative antara dua variabel bebas dan satu variabel terikat yaitu yaitu pengetahuan deklaratif dan pengetahuan prosedural dengan keterampilan proses sains.

Pada hasil uji persamaan regresi linear berganda diperoleh nilai a sebesar 4,659, nilai $b_{1}$ sebesar 0,223 dan nilai $b_{2}$ sebesar 0,448 sehingga didapatkan persamaan $\widehat{Y}=4,659+$ $0,223 X_{1}+0,448 X_{2}+\varepsilon$. Persamaan tersebut menunjukkan bahwa pengetahuan deklaratif dan pengetahuan prosedural jika nilainya konstan maka rata-rata keterampilan proses sains peserta didik sebesar 4,659, sedangkan ketika pengetahuan deklaratif peserta didik sebesar 0,223 dengan nilai positif maka ini menunjukkan bahwa setiap kenaikan 1 konstanta pada pengetahuan deklaratif akan meningkatkan keterampilan proses sains peserta didik sebesar 0,223, dan ketika pengetahuan prosedural peserta didik sebesar 0,448 dengan nilai positif maka ini menunjukkan bahwa setiap satu kenaikan 1 konstanta pada pengetahuan prosedural akan meningkatkan keterampilan proses sains peserta didik sebesar 0,448 . Standar error $(\varepsilon)$ untuk persamaan ini diperoleh dari koefisien determinasi yang diperoleh dari uji korelasi yaitu sebesar 0,127 berarti $\varepsilon=1-r^{2}=1-0,127=0,873$ artinya bahwa sumbangan variable bebas terhadap variable terikat sebesar $12,7 \%$, sisanya mencerminkan adanya pengaruh variabel lain tetapi tidak diteliti sebesar $87,3 \%$.

Untuk uji signifikansi regresi linier bergandadidapatkan hasil $F_{\text {hitung }}>F_{\text {tabel }}, 31,909>3,86$ maka $H_{o}$ ditolak. Sehingga persamaan regresi $\hat{Y}=4,659+0,223 X_{1}+0,448 X_{2}+\varepsilon$ signifikan atau terdapat pengaruh linier variabel $X_{1}$ dan $X_{2}$ dengan variabel $Y$.

\section{Pembahasan}

Berdasarkan hasil analisis data untuk persamaan regresi pengetahuan deklaratif dengan keterampilan proses sains didapatkan bahwa terdapat hubungan yang positif antara pengetahuan deklaratif dengan keterampilan proses sains peserta didik. Ini artinya ketika pengetahuan deklaratif peserta didik berada pada kategori baik maka keterampilan proses sains juga akan berada pada kategori baik. Pengetahuan deklaratif memiliki hubungan yang sangat rendah dengan keterampilan proses sains peserta didik. Walaupun tergolong dalam kategori sangat rendah namun pengetahuan deklaratif memberikan pengaruh yang positif dan signifikan yang dapat meningkatkan keterampilan proses sains peserta didik.

Keterampilan proses sains peserta didik tidak sepenuhnya berasal dari pengetahuan deklaratif saja. Namun untuk hasil yang maksimal dalam keterampilan proses sains, peserta didik perlu diberikan pemahaman mengenai pengetahuan deklaratif. Hal ini mengacu pada pernyataan Ulmiah, Andriani \& Fathurohman (2016) yang menjelaskan bahwa pengetahuan deklaratif meliputi fakta-fakta, prinsip, model konseptual, teori dan hukum di mana siswa mampu memahami dan mengingat. Salah satu cara guru mengembangkan keterampilan proses sains adalah melakukan kegiatan pembelajaran yang mengembangkan aktivitas belajar siswa. Aktivitas belajar siswa akan 
berkembang apabila pembelajaran yang dilakukan melibatkan siswa secara aktif. Pelibatan siswa secara aktif dalam pembelajaran akan membantu siswa memahami konsep-konsep yang akan disampaikan bukan hanya sekedar hafalan saja. Siswa dilibatkan dalam proses penyelidikan pembenaran suatu konsep dengan melaksanakan investigasi. Ketika siswa melakukan penyelidikan dan menginvestigasi suatu masalah secara ilmiah dengan cara mencari dan mengumpulkan buktibukti, siswa melakukan banyak sekali aktivitas belajar sehingga dapat membantu siswa untuk mengembangkan keterampilan proses sains yang pada dasarnya dimiliki oleh setiap siswa. Hal ini menunjukkan bahwa pemahaman akan konsep-konsep berhubungan dengan peningkatan keterampilan proses sains.

Begitu pula dengan hasil regresi linier sederhana pada pengetahuan prosedural dengan keterampilan proses sains peserta didik, diperoleh bahwa terdapat hubungan yang positif pengetahuan prosedural dengan keterampilan proses sains. Ini artinya ketika pengetahuan prosedural peserta didik berada pada kategori baik maka keterampilan proses sains juga akan berada pada kategori baik. Berdasarkan analisis data pengetahuan prosedural memiliki hubungan yang rendah dengan keterampilan proses sains peserta didik. Walaupun tergolong rendah, namun pengetahuan pengetahuan prosedural memberikan pengaruh yang positif dan signifikan yang dapat meningkatkan keterampilan proses sains peserta didik.

Menurut Sugiyono (2015) harga b merupakan fungsi dari koefisien korelasi. Bila koefisien korelasi tinggi, maka harga b juga besar, sebaliknya bila koefisien korelasi rendah maka harga b juga rendah (kecil). Selain itu bila koefisien korelasi negatif maka harga b juga negatif, dan sebaliknya bila koefisien korelasi positif maka harga $b$ juga positif. Kesalahan residual $(\varepsilon)$ mencerminkan pengaruh variabel lain yang telah teridentifikasi oleh teori tetapi tidak diteliti atau variabel lainnya yang belum teridentifikasi oleh teori dengan kesalahan/kekeliruan pengukuran (Kadir, 2015).

Berdasarkan pernyataan Sugiyono (2015) dan Kadir (2015) tersebut dinyatakan bahwa pengetahuan deklaratif berpengaruh positif dimana harga $b$ pada persamaan regresi adalah 0,2482 , dan kesalahan residual sebesar 0,9868. Pengetahuan prosedural juga berpengaruh positif dimana harga b pada persamaan regresi sebesar 0,9046 , dan kesalahan residual sebesar 0,8747 mencerminkan adanya pengaruh variabel lain tetapi tidak diteliti.

Berdasarkan hasil analisis regresi linier berganda diperoleh hasil bahwa pengetahuan deklaratif dan pengetahuan prosedural memiliki hubungan yang positif dengan keterampilan proses sains peserta didik kelas VIII SMPN Terakreditasi A di Kota Makassar. Dari hasil uji korelasi pengetahuan deklaratif dan pengetahuan prosedural dengan keterampilan proses sains memiliki tingkat hubungan yang rendah. Walaupun memiliki tingkat hubungan yang rendah tetapi pengetahuan deklaratif dan pengetahuan prosedural memberikan sumbangsih yang positif pada keterampilan proses sains peserta didik. Hal ini dapat dilihat dari persamaan regresi yang diperoleh dari hasil analisis inferensial data penelitian yang telah dipaparkan sebelumnya.

\section{KESIMPULAN}

Berdasarkan hasil penelitian yang dilakukan tentang hubungan antara pengetahuan deklaratif dan pengetahuan prosedural dengan keteampilan proses sains peserta didik kelas VIII SMPN Terakreditasi A Di Kota Makassar disimpulkan bahwa:

1. Pengetahuan deklaratif peserta didik kelas VIII SMPN Terakreditasi A Di Kota Makassar memiliki rata-rata skor keseluruhan sebesar 3,87 termasuk dalam kategori sangat rendah.

2. Pengetahuan prosedural peserta didik kelas VIII SMPN Terakreditasi A Di Kota Makassar memiliki rata-rata skor keseluruhan sebesar 5,25 termasuk dalam kategori sangat rendah.

3. Keterampilan proses sains peserta didik kelas VIII SMPN Terakreditasi A Di Kota Makassar memiliki rata-rata skor keseluruhan sebesar 7,87 termasuk dalam kategori sangat rendah. 
4. Terdapat hubungan positif antara pengetahuan deklaratif dengan keterampilan proses sains peserta didik kelas VIII SMPN Terakreditasi A Di Kota Makassar sebesar 1,32\%, dengan tingkat hubungan sangat rendah.

5. Terdapat hubungan positif antara pengetahuan prosedural dengan keterampilan proses sains peserta didik kelas VIII SMPN Terakreditasi A Di Kota Makassar sebesar 11,7\%, dengan tingkat hubungan rendah.

6. Terdapat hubungan positif antara pengetahuan deklaratif dan pengetahuan prosedural dengan keterampilan proses sains peserta didik kelas VIII SMPN Terakreditasi A Di Kota Makassar sebesar $12,7 \%$, dengan tingkat hubungan rendah.

\section{DAFTAR PUSTAKA}

Anderson. (2015). Kerangka Landasan Untuk Pembelajaran, Pengajaran dan Asesmen (Revisi Taksonomi Pendidikan Bloom). Yogyakarta: Pustaka Belajar.

Ardhana, I.A. (2020). Dampak Process-Oriented Guided-Inquiry Learning (POGIL) terhadap Pengetahuan Metakognitif Siswa pada Topik Asam-Basa. HYDROGEN: JURNAL KEPENDIDIKAN KIMIA JUNI 2020. VOL.8, NO.1 E-ISSN: 2656-3061 PP.1-10

Arifin, Z. (2014). Evaluasi Pembelajaran. Bandung: PT Remaja Rosdakarya Offset.

Depdiknas. (2003). Undang-undang RI No.20 tahun 2003. Sistem Pendidikan Nasional.

Hasan, M. I. (2012). Pokok-pokok Materi Statistik 2 (Statistik Inferensif) Edisi Kedua. Jakarta: PT. Bumi Aksara.

Hayu, R. M., Ardi, \& Yanti, F. (2017). Hubungan Kemampuan Metakognisi Dengan Hasil Belajar IPA Siswa Kelas VIII Di Mtsn Kuranji Padang. Jurnal Inovasi Pendidikan IPA .

Hırça, N. (2013). The Influence Of Hands On Physics Experiments On Scientific Process Skills According To Prospective Teachers' Experiences. European J Physics Education .Arifin, Z. (2014). Evaluasi Pembelajaran (Prinsip, Teknik, Prosedur). Bandung: PT Remaja Rosdakarya.

Jufri, W. (2017). Belajar dan Pembelajaran Sains: Modal Dasar Menjadi Guru Profesional. Bandung: Penerbit Pustaka Reka Cipta.

Kadir. (2015). Statistika Terapan: Konsep, Contoh, dan Analisis dengan Program SPSS/Lisrel dalam Penelitian. Jakarta: PT. Raja Grafindo Persada

Kastawaningtyas, A., \& Martini. (2017). Peningkatan Keterampilan Proses Sains Siswa Melalui Model Experiential Learning Pada Materi Pencemaran Lingkungan. Jurnal Penelitian Pendidikan IPA.

Keil, C., Haney, J., \& Zoffel, J. (2009). Improvements in Student Achievement and Science Process Skills Using Environmental Health Science Problem-Based Learning Curricula. Electronic Journal of Science Education .

Kurniati, T. (2001). Keterampilan Proses Sains Untuk Meningkatkan Keterampilan Berpikir Kritis Siswa. Tesis. PPs UPI Bandung: Tidak diterbitkan 
Lestari, S., Mursali, S., \& Royani, I. (2018). Pengaruh Model Pembelajaran Langsung Berbasis Praktikum terhadap Keterampilan Proses Sains dan Kemampuan Berpikir Kritis Siswa. BIOSCIENTIST : JURNAL ILMIAH BIOLOGI, 6(1), 67-79. doi: https://doi.org/10.33394/bjib.v6i1.2367

Permendikbud. (2013). Implementasi Kurikulum 2013. Jakarta.

Ratumanan, T. G., \& Laurens, T. (2003). Evaluasi Hasil Belajar yang Relevan dengan Kurikulum Berbasis Kompetensi. Surabaya: YP3IT.

Rezba, R. J. (2007). Learning and Assessing Science Process Skills. Kendall: Kendall/Hunt Publishing Company.

Rinaldi. (2017). Kesadaran Metakognitif. Jurnal RAP UNP.

Rustaman, A. (2005). Pengembangan Kompetensi (Pengetahuan, Keterampilan, Sikap, Dan Nilai) Melalui Kegiatan Praktikum Biologi. Penelitian Jurusan Pendidikan Biologi FPMIPA UPI Bandung.

Sugiyono. 2013. Metode Penelitian Pendidikan Pendekatan Kuantitatif,. Kualitatif, dan R\&D. Bandung: Alfabeta.

Sugiyono. (2015). Statistik untuk Penelitian. Bandung: Alfabeta.

Tawil, M., \& Liliasari. (2014). Keterampilan-Keterampilan Sains dan Implementasinya Dalam Pembelajaran IPA. Makassar: Badan Penerbit UNM.

Ulmiah, N., Andriani, N., \& Fathurahman, A. (2016). Studi Keterampilan Proses Sains Siswa SMA Kelas $X$ pada Pembelajaran Fisika Pokok Bahasan Suhu dan Kalor Melalui Model Pembelajaran Kooperatif Tipe Group Investigation di SMA Negeri 11 Palembang. Jurnal Inovasi dan Pembelajaran Fisika Issn: 2355 - 7109

Wildayati, Sartika, R.P., \& Lestari, I. (2020). Penerapan Metode praktikum materi asam, basa, dan garam terhadap keterampilan proses sains siswa smp. Jurnal Pendidikan dan Pembelajaran khatulistiwa. vol. 9 no.4. 


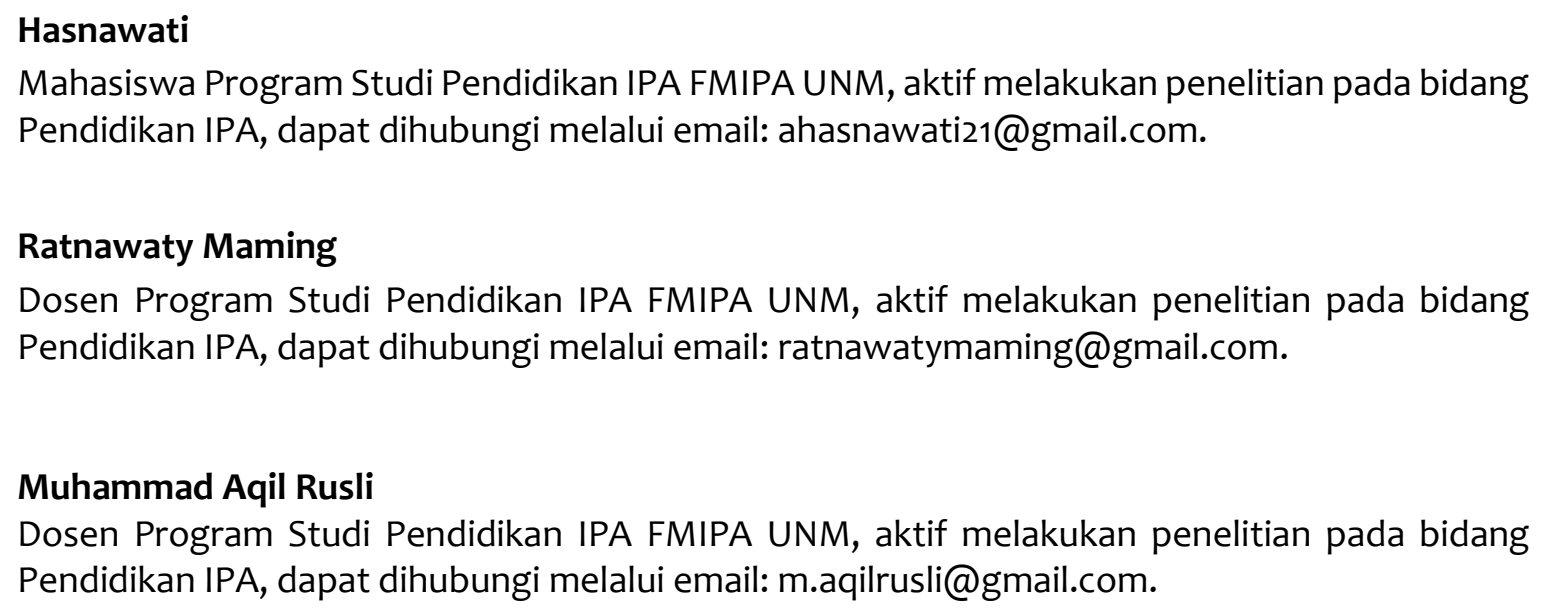

Mahasiswa Program Studi Pendidikan IPA FMIPA UNM, aktif melakukan penelitian pada bidang Pendidikan IPA, dapat dihubungi melalui email: ahasnawati21@gmail.com.

\section{Ratnawaty Maming}

Dosen Program Studi Pendidikan IPA FMIPA UNM, aktif melakukan penelitian pada bidang Pendidikan IPA, dapat dihubungi melalui email: ratnawatymaming@gmail.com.

\section{Muhammad Aqil Rusli}

Dosen Program Studi Pendidikan IPA FMIPA UNM, aktif melakukan penelitian pada bidang Pendidikan IPA, dapat dihubungi melalui email: m.aqilrusli@gmail.com. 